\title{
Conclusion: A Church in the World
}

Our study opened with a seemingly simple question: what was Manichaeism to Horos and Horion? We proposed to answer this question by approaching 'Manichaeism' primarily as social practice, and by exploring the intricate ties between the people of the House 1-3 archive. In this concluding chapter, we shall pull together some threads and sketch some of the answers yielded by this approach. At the same time, we shall consider the implications of these answers for two broader issues, issues that we have already touched on in some of the foregoing chapters: the dichotomy between 'lived religion' and authoritative religious institutions, and the emergence of 'religion' as a separate social sphere in late antiquity.

First, to summarise the findings, this study has argued that the House 1-3 material evinces a vibrant religious community active in Kellis. Religious ties were intertwined with familial ties, neighbourhood ties, and ties of trade within the network of the Pamour family of House 3. The community included artisans and tenant farmers as well as traders, and at least one patron from the curial class. In terms of size, the group of adherents that can be glimpsed in the House 3 texts was extensive, relative to the village at large. The literary remains indicate that the group held gatherings for religious service, such as psalm singing, although we do not know where or how often they met for service, or how many attended regularly.

Equally, it has been argued that the material provides evidence for the trans-local dimensions of the community, the ways local adherents were linked to a wider Manichaean world. They alluded to their membership in a wider church community with phrases drawn from Manichaean literature. They made use of prayers and psalms which brought them into contact with the Manichaean cosmos, and Epistles wherein Mani described how he founded this new Church as distinct from other 'sects'. Not least, they had actual ties to such a community, through extensive interaction with adherents in other parts of Egypt - including several Elect. While our sources do not chiefly relate to Elect activities, the glimpses we do get suggest that they sought to reinforce ties to the local community while maintaining a wider church organisation. 
Let us now turn to the central issue that arose from the letter of Horion. As we have seen, recent scholarship has used the Christian aspects of the Kellis material to support the argument that Manichaean laity considered their affiliation as a form of higher 'Christianity', supported by an assumption that the Auditors at Kellis mainly engaged with the Christian elements of Mani's teachings. The implications appear to be that the Elect either consciously withheld more 'Manichaean' aspects from the laity, or that the laity were uninterested in them. ${ }^{1}$ At the same time, it has been proposed that Mani's original Church was essentially a Christian movement, which developed and solidified into a separate 'Manichaeism' through the work of later church authorities. ${ }^{2}$ On this view, the primarily Christian identity of the Kellis laity represents a more original strain, one which church authorities presumably strove to replace with a more 'Manichaean' identity.

Neither proposition is satisfactory. Roman Manichaeans certainly saw themselves as in some sense 'Christian', but 'Christian' as conceptualised by Mani and his early followers. In terms of 'belief', this involved an original battle between Light and Darkness, a series of gods that emanated from the primeval Light, a world soul partitioned and imprisoned in matter through transmigration, and the purification of Light through natural and metabolic processes, buttressed by the revelations and authority of Mani. In terms of practice, it involved a variety of self-techniques (such as daily prayers), communal rituals, and mutual cooperation between Elect and Auditors. In the course of this study, we have seen that while their knowledge was certainly not as thorough as that of the Elect, distinctly Manichaean ideas and practices were appropriated by the fourth-century laity in Kellis. They should not be seen as practicing a form of 'Christianity' opposed to an Elect 'Manichaeism'.

Nor does it seem that it was primarily later Manichaean authorities who consciously made the notion of 'Manichaeism' in an attempt to distance themselves from 'Christianity'. On the one hand, the term 'Manichaean' was not a prerequisite for the development of what we, in scholarly parlance, term a Manichaean identity. The term 'Manichaean' has, in fact, not been found

1 So for instance P.Kellis II, ix-x; Nongbri, Before Religion, 72.

2 Thus Pedersen, 'Manichaean Self-Designations', 193. 
even in the much later Central-Asian evidence. ${ }^{3}$ On the other hand, a categorisational scheme that implied a separation of 'Manichaeism' from 'Christianity' was already present in early Manichaean literature. The process of differentiating the two must have begun with Mani in the Sasanian Empire, as he encountered resistance to his claims of supercession among other Christians as well as Mazda-worshippers (and perhaps Buddhists?). This would have marked his 'Church' off as a distinct social entity at an early date: an entity constituted by distinct notion of belief and practices, or 'a group that holds opinions far different from others and has established for itself a worship of the deity with a far different ritual', in the words of the Manichaean bishop Faustus. ${ }^{4}$ This did not stop Manichaeans from asserting their own primacy, and so it is no surprise that Mani's adherents maintained their claims to be superior 'Christians' in the Roman Empire and 'Mazda-worshippers' in Central-Asia, even as their point of referance for understanding these traditions remained Mani, his teachings, and his Church. ${ }^{5}$ But, for the sake of analytical clarity, it does imply that modern scholars cannot simply adopt their self-designations.

The question of Manichaean identity is related to wider questions, questions concerning how we are to understand the concept of 'religious identity' in late antiquity. It is particularly relevant to the question of how we are to conceptualise lay resistance to religious authorities, and the fluid, situational nature of identities more broadly. Scholars focused on these aspects of ancient religion have provided a necessary corrective to older scholarship, which often dogmatically transplanted practices and interpretations from canonical texts onto the lives of lay people, creating images of solidified, doctrine-centred 'religions'. At the same time, some recent scholarship within the 'lived religion' tradition has ascribed a much too limited role to religious institutions. While rejecting an absolute distinction between 'popular' and 'elite' religion, the general tenor has been to consider religious authorities and the practices they promoted as having little influence on everyday religious expressions. In a recent volume, Jörg Rüpke and Erik Rebillard cite with approval the rejection of the dichotomy elite-lay by Virginia Burrus and Rebecca Lyman, but propose that we need to

3 As pointed out by Pedersen, 'Manichaean Self-Designations', 193 n.38.

4 C. Faust. 20.3, trans. Teske, Against Faustus, 264.

5 Pedersen, 'Manichaean Self-Designations', op. cit. 
emphasise 'individual innovations, variations, manipulations, or deviances.' ${ }^{6}$ David Frankfurter, while repeatedly pointing out the co-dependence between lay expressions and authoritative institutions, ${ }^{7}$ nonetheless focuses almost exclusively on creative appropriation of such institutions, paying little attention to the processes that gave rise to their 'authority' in the first place. ${ }^{8}$ Mattias Brand similarly points out the inadequacy of the conflict model of lay contra institutional religion, but concludes that religious identity was chiefly important for the Elect and only had limited relevance to the everyday life of lay adherents at Kellis. ${ }^{9}$

As we have seen in the course of this study, this does not properly capture the life of the community there. The evidence rather suggests lay people who actively appropriated and expressed shared Manichaean identity in their day-to-day lives. Appropriation entailed a large degree of reproduction of practices drawn from authoritative traditions: practices such as church readings, psalm singing, individual prayer, book copying, and almsgiving to the Elect. Elect authorities made great efforts to assist in this reproduction by maintaining close ties to the laity, through religious services and frequent visits. Of course, it should not be taken to mean that Manichaean identity superseded or replaced all other identities. The inhabitants of House 1-3 probably considered 'religion' to be irrelevant in many settings, de-emphasised or disregarded norms and ideas when it suited them, produced idiosyncratic takes on Manichaean institutions, and at times came to blows with the Elect. Communal institutions would have had to adapt to circumstances, and at times been neglected or even collapsed, whether because of external pressure or internal factors. Yet, for the most part, the modes of identification and practices that we do find at Kellis agree well with what we know from 'canonical' Manichaean texts. The fact that identities are, to some extent, situational and fluid should not therefore lead us to exclude a degree of continuity in the maintenance of group boundaries, or to consider religious norms and ideas as inherently irrelevant to - or, as has often been the case for Manichaeism, incompatible with - the laity's mundane world.

6 Erik Rebillard and Jörg Rüpke, 'Introduction', in Group Identity and Religious Individuality in Late Antiquity (Washington, DC: Catholic University of America Press, 2015), 6.

7 See e.g. Frankfurter, Christianizing Egypt, 52 .

8 As noted in a recent review by the anthropologist Candace Lukasik ('Christianizing Egypt: Syncretism and Local Worlds in Late Antiquity', Political Theology 19, no. 6 (2018), 545).

9 Brand, 'Manichaeans of Kellis' 337-45. 
Finally, this discussion brings us to our study's implications for the shift in ancient religiosity: the emergence of 'religion' as a distinct social sphere in late antiquity. That such a shift occurred is widely, although not universally, acknowledged. ${ }^{10}$ Yet disagreements remain over its nature and extent. Scholars focused on the fluid nature of identities and the opposition authorities contra laity have argued that it was primarily one of elite discourse, driven by religious specialists, which had little effect on the lives of ordinary people. ${ }^{11}$ However, it seems to me that we cannot understand this shift without at the same time locating it in concrete social structures - new institutions and organisational forms - which in turn disseminated new forms of religious identification in broader society. ${ }^{12}$

To get a sense of what characterised this institutional development, we may briefly compare the features identified for the Kellis community to those generally found in the so-called voluntary associations of classical and early Roman antiquity, the dominant model of private religious organisations in the time before Manichaeism. ${ }^{13}$ Certainly, 'voluntary associations' is a modern concept, subsuming a heterogeneous range of group formations from different times and places in a single category, but some features seem sufficiently common to provide an 'ideal type' for comparison. ${ }^{14}$ Voluntary associations ranged from cultic to occupational ones, but all featured cultic practice in one form or another. ${ }^{15}$ Many kept membership lists, which show that they could range in size from only a few to several hundred members, although on average

10 See North, 'The Development of Religious Pluralism'; Stroumsa, End of Sacrifice; James Rives, 'Religious Choice and Religious Change in Classical and Late Antiquity: Models and Question', ARYS 9 (2011): 265-80; BeDuhn, 'Mani and the Crystallisation'.

11 Rebillard, Christians and their Many Identities, 93-94; Frankfurter, Christianizing Egypt.

12 In line with the argument of James Rives, 'Religious Choice'.

13 For the term, see Stephen G. Wilson, 'Voluntary Associations: An Overview', in Voluntary Associations in the Graeco-Roman World, ed. John S. Kloppenborg and Stephen G. Wilson (London: Routledge, 1996).

14 For the debate about the usefulness of this term as a heuristic model, see Richard S. Ascough, 'Paul, Synagogues, and Associations: Reframing the Question of Models for Pauline Christ Groups', Journal of the Jesus Movement in its Jewish Setting 2 (2015); Eric S. Gruen, 'Synagogues and Voluntary Associations as Institutional Models: A Response to Richard Ascough and Ralph Korner', Journal of the Jesus Movement in its Jewish Setting 3 (2016); Richard S. Ascough, 'Methodological Reflections on Synagogues and Christ Groups as Associations: A Response to Eric Gruen', Journal of the Jesus Movement in its Jewish Setting 4 (2017).

15 See Wilson, 'Voluntary Associations'; Harland, Associations, 30-38. 
the number was somewhere between 20-60. ${ }^{16}$ Specialised cultic associations could be based in households or centred on households of wealthy benefactors. Widely shared functions included organising communal meals and cultic observance, and funerals for members. ${ }^{17}$ Members contributed to financing these activities, elected and/or served as officials, and participated in communal gatherings. Their meetings could be held in public spaces, in the houses of wealthy patrons, or in buildings owned by the association as an entity. ${ }^{18}$ They involved banqueting, but also prayers and in some groups speeches about the divine. ${ }^{19}$ Associations often sought to regulate social behaviour among its members, rewarding generous members with statues or honorific inscriptions, and imposing punishments such as shaming inscriptions, fines, or expulsion for breaches of good conduct. ${ }^{20}$

This short sketch should suffice to show some broad similarities between voluntary associations and the Manichaean community discernible in the Kellis material. It lacked some features, such as membership lists, but shared in most others, such as mechanisms for collecting and distributing resources, communal spaces, official supervision, and norms to regulate group relations. But it also evinces traits that were previously uncommon or marginal: communal textual practices, frequent and regular (in theory, daily) communal meetings, mobile officials with institutionalised, trans-local ties, and strong concerns for internal conformity (even if, as is often pointed out, never achieving this unattainable ideal in practice). ${ }^{21}$ There may exist earlier parallels, for instance

16 John S. Kloppenborg, 'Membership Practices in Pauline Christ Groups', Early Christianity 4, no. 2 (2013).

17 Harland, Associations, 28.

18 Ibid., 53-56; for the spread of associations as evinced by the expansion or acquisition of buildings, see Richard S. Ascough, "A Place to Stand, a Place to Grow": Architectural and Epigraphic Evidence for Expansion in Greco-Roman Associations', in Identity and Interaction in the Ancient Mediterranean: Jews, Christians and Others. Festschrift for Stephen G. Wilson, ed. Zeba Crook and Philip Harland (Sheffield: Sheffield Phoenix Press, 2007). For the assembly place of an early 'Christ group', see David G. Horrel, 'Domestic Space and Christian Meetings at Corinth: Imagining New Contexts and the Buildings East of the Theatre', New Testament Studies 50 (2004).

19 See IG II ${ }^{2} 1368=$ AGRW 7 (l.115).

20 Kloppenborg, 'Membership Practices', 195-202; Venticinque, 'Family Affairs', 280-88.

21 So, while textual practices may have played a role in Graeco-Roman associations (Richard Last, "Communities That Write": Christ-Groups, Associations, and Gospel Communities', New Testament Studies 58, no. 2 (2012)), one should compare the distinct Christian book culture that emerged in the third and fourth century. See Lane Fox, 'Literacy and Power'; Walter Burkert, Ancient Mystery Cults (Cambridge, Mass.: Harvard University Press, 1987), 70-72. For concerns for conformity, contrast the use of inscriptions to honour or shame 
among Jewish groups, or philosophical schools such as the Epicureans. ${ }^{22}$ The Manichaeans' own institutions were certainly assembled from a range of different influences. ${ }^{23}$ Rather than 'innovation' per se, what characterised the late antique shift in religion is perhaps better described as the assemblage of 'packages' of institutionalised practices, integrated into and disseminated by new religious organisations. Such organisations are not least exemplified by the 'mainstream' Christian Church, which developed partly in parallel with the

members with the level of scrutiny discussed in Chapter 9 (Section 2), and see the use of confession discussed in BeDuhn, 'Manichaean Weekly Confession'. Confession is not documented at Kellis, but mention of it occurs in Psalm 222, a psalm partly preserved in T.Kellis II Copt. 4a. Some evidence for trans-local ties, mostly informal, can be found for associations, but it is very sparse. See Richard S. Ascough, 'Translocal Relationships among Volunatry Associations and Early Christianity', Journal of Early Christian Studies 5, no. 2 (1997).

Richard S. Ascough, 'Greco-Roman Philosophic, Religious, and Voluntary Associations' in Community Formation in the Early Church and in the Church Today, ed. Richard N. Longnecker (Peabody: Hendrickson, 2002), 7-8.

23 Its structure clearly drew on a variety of sources, both for the hierarchy and for the Elect-Auditor division. The Marcionite community has been suggested as a central mediator of Christian influence, and an inspiration for its bipartite division and use of 'bishops' (e.g. Puech, Sur le manicheisme, 253-54; Lieu, Manichaeism in the Roman Empire, 32-37). But Manichaean 'cosmic' concerns have also been suggested: Tardieu (Manichaeism, 59) pointed to a possible astrological aspect to the division 12 Teachers, 72 bishops, and 360 presbyters (the latter number found in the eastern tradition), an argument that has been more fully developed by Leurini, who links it to Manichaean divinities ('The Manichaean Church between Earth and Paradise', in New Light on Manichaeism, ed. Jason D. BeDuhn (Leiden: Brill, 2009); The Manichaean Church, 91-157). Both interpretations now receive support from the Dublin Kephalaia, which contains a chapter where Mani is asked by Gundesh, a sage, to explain the structure of the community (specifically, the institution of 12 Teachers and 72 bishops). BeDuhn notes: 'Mani connects these ranks both with the two groups of disciples that Jesus selected (in Luke and the Diatessaron), and with hierarchies of angels.' BeDuhn, 'Parallels', 70. The 'Elchasaite' sect of Mani's youth (or similar groups of 'baptists') was also a source of influence. The Abbasid historian al-Ma'sūdī claimed that 'the Christians took some of these (ecclesiastical) offices from the Saābians; the Manichaeans did (likewise) with that of "priest," "deacon," and the rest, although not those of the "electi," "auditores," etc.' Reeves, Prolegomena, 208; see also Koenen, 'Manichäische Klöster', 99-100; Reeves, 'The "Elchasaite" Sanhedrin'; Stanley F. Jones, 'The Book of Elchasai in its Relevance for Manichaean Institutions', ARAM 16 (2004). The leadership structure found in some Qumran texts has been considered the closest parallel for the early Christian church structure as well, providing perhaps a common source for Christians and Manichaeans (Lane Fox, Pagans and Christians, 495). There are good reasons to see the main feature, Mani's division between 'Elect' and 'Auditor', as influenced by Indian traditions, either by way of writers like Bardaisan or by his own encounters with Indian ascetics, as seen in the particular way the role of the Elect was developed. See Deeg and Gardner, 'The Case of Jainism'; Dilley, 'Mani's Wisdom', 5o. 
Manichaean one - and which, when later paired with the Roman state apparatus, developed into a highly effective organisation for its time. ${ }^{24}$ Others, such as the Jewish patriarchate, represent a similar tendency in the same period. ${ }^{25}$

These developments had consequences on the level of the individual, not least in that the emergence of new social institutions is strongly linked with the production of religious identities. As James Rives has pointed out:

With respect to religious identity, then, what really distinguished classical antiquity from late antiquity, the world of Plutarch from that of Julian, was thus not a change in the inner experience of the individual or even the availability of religious choices that entailed profound implications for a person's worldview and way of life; it was rather the existence of social structures that forced individuals to accept those implications, publicly if not always personally. ${ }^{26}$

This should not be taken to mean that religious identity was only a question of imposition from above. It must be remembered that authoritative discourses are always produced by specific institutions located within wider networks of power, which, in the case of the Manichaeans, required voluntary participation. While Christian bishops, in the later fourth century, could use the tools of the Roman government to bolster their authority, other movements never attained such influence. The authority of Manichaean

24 For the growth of Christian institutions up to the fourth century, see Lane Fox, Pagans and Christians, 493-517; Beard, North, and Price, Religions of Rome, 304-6; Rapp, Holy Bishops, 24-37. The growth of episcopal power in the wake of Constantine's support for the Church can for instance be seen in the subordination of funerary associations to bishops by Constantine and later emperors, see Sarah E. Bond, 'Mortuary Workers, the Church, and the Funeral Trade in Late Antiquity',Journal of Late Antiquity 6, no. 1 (2013). For episcopal influence in the fourth century in general, see e.g. Peter Brown, Power and Persuasion. It is generally agreed that the Jewish patriarchate begun to assert itself within the Jewish community by the final quarter of the second and early third century CE at the latest, under Yehudah ha-Nasi (Judah the Patriarch), although there is considerable disagreement concerning its development and influence. See David M. Goodblatt, 'The Political and Social History of the Jewish Community in the Land of Israel, c.235-638', in The Cambridge History of Judaism. Volume 4: The Late Roman-Rabbinic Period, ed. Steven T. Katz (Cambridge: Cambridge University Press, 2008), 417-23. Whether the patriarch succeeded is of lesser import here; the central argument is that the patriarchate's development parallels attempts among Christians and Manichaeans to develop nominally centralised, trans-local organisations (originally) outside a political framework, using religious authorities - Rabbis - as officials, even if the relationship between the patriarchate and the Rabbis is also a somewhat contentious matter; see ibid. 
Elect was dependent on the laity's voluntary appropriation of their institutions: they had no mechanisms for imposing almsgiving, prayer, confession, or belief in Light Souls. The laity themselves must have found appeal in what these institutions offered: new forms of individual and communal self-practices, new techniques for gaining access to divine power, and participation in wider social networks with a shared sense of identity. And while Frankfurter is correct in pointing out that local appropriation would often be driven by local concerns, ${ }^{27}$ we should not underestimate the dialectical relationship through which institutions could shape the way such concerns were conceived of.

Certainly, there were limits to their ability to shape identities and practices, as has previously been discussed. We should be careful not to mistake the 'Manichaean Church' of Egypt for a bounded or finished entity, an identical copy of the 'mother church' in Mesopotamia. The spread of religious movements always involves processes of 'interpretation, localisation, and indigenisation', to borrow a phrase from Frankfurter. ${ }^{28}$ Re-making 'Manichaeism' in a Roman, in an Egyptian, or in an Oasite context entailed translations and compromises, conscious and unconscious adaptions, in which local networks played their part. Maintaining what authorities took to be central features would have required constant attention to local conditions as well as boundaries of identity. Yet, 'localisation' was not the only force at work. The interlinked nature of the organisations, and the reproduction of texts and institutional templates, made sure that change happened in continuous dialogue with existing traditions, as the finds from Kellis attest to. They also highlight how widespread this process was. The existence of a Manichaean community in a remote area of Egypt, established without state support and less than a century after the movement's founding in distant Mesopotamia, showcases the wide reach of these social organisations. The emergence of the new social sphere of 'religion' was felt even on the village level. Its consequences would ripple through the Mediterranean world and beyond.

As one of the reasons for why his Church was superior to all others, the Berlin Kephalaia presents Mani as saying: 'My church will remain henceforth and be unveiled through the world ... it has attained its fastness and cannot be shaken,

27 Frankfurter, Christianizing Egypt, 31.

28 Ibid., 72 . 
continuing on till the end of the world. ${ }^{29}$ Despite its relative success, the Church did not remain fixed, nor did it last until the end of the world. Its dissolution may have begun already in the fifth century. Peter Brown was probably correct in identifying changes in trading patterns and the growth in Christian episcopal power in the fifth and sixth centuries as central factors in the decline, along with hostility from the Roman state. ${ }^{30}$ Such changes made it increasingly difficult for adherents to disseminate literature, for Elect to find gathering places or safe havens of support, and for the maintenance of trans-regional or even trans-local contact between communities. It is highly unlikely that contact between Manichaeans in, for instance, Egypt and Mesopotamia would have survived long into this period. Nonetheless, much work on Manichaeism remains to be done. Forthcoming volumes of the remaining Medinet Madi codices will undoubtedly add much to our knowledge of the history, ideas, and self-understanding of the Manichaean Church. Textual material from Kellis remains unpublished and perhaps undiscovered, as do material from neighbouring sites such as Ain el-Gedida, Mut, and Amheida. New finds may occasion a need to revisit the prosopography and other arguments proposed here.

Kellis appears to have been abandoned around 400 CE. What happened to the Manichaean community there remains unknown. The people we have glimpsed in the House 1-3 archive probably lived on, settling elsewhere in the Oasis, or in Aphrodito or other places in the Nile Valley, but we do not know whether or for how long they maintained support for the 'Holy Church'. The evidence for Manichaeans in Egypt in general fades away at this time. The later developments and eventual demise of Manichaeism in Egypt go undocumented. A seventh-century patriarch of the Coptic Christian Church, Benjamin of Alexandria, recounts a story about two travelling Manichaeans who were executed by the dux of Egypt in $643 \mathrm{CE}$, but its veracity cannot be ascertained. ${ }^{31}$ According to ibn al-Nadim, an 'African' named Abu Hilal al-Dayhuri was appointed leader (i.e. archegos) of the Manichaeans in Iraq during the caliphate of al-Mansur $\left(754^{-} 775 \mathrm{CE}\right)$. His epithet probably signifies an origin in Egypt: it does not, however, prove the continuous existence of the Church here from the fourth century. ${ }^{32}$

In 527, during the last major persecution of Manichaeans in the Roman Empire, a leader of the Manichaeans named Photeinos was brought out in chains and forced to debate a leading theologian, Paul, in the city of

$29 \quad 1$ Ke. 371.31-372.10 (abbreviated), trans. Gardner and Lieu, Manichaean Texts, 266.

30 Brown, 'Diffusion of Manichaeism'.

31 See Gardner and Lieu, Manichaean Texts, 123.

32 See Reeves, Prolegomena, 266 n.78. 
Constantinople. ${ }^{33}$ If this account has historical veracity, as is generally accepted, Photeinos likely presided over the last vestiges of a Manichaean Church in the Roman Empire. The Church survived in Mesopotamia and Iran for yet another three centuries. Persecutions under the Abbasids weakened it, made it increasingly reliant on ties to Central Asia, and in the end put it to flight. ${ }^{34}$ But even if the larger 'Church' disappeared, pockets of adherents may have survived in specific localities; remains of networks similar to those of the Manichaean families in fourth-century Kellis.

33 Lieu, Manichaeism in the Roman Empire, 171-73; Byard Bennet, 'Paul the Persian', Encyclopedia Iranica Online (2003), http://www.iranicaonline.org/articles/paul-the -persian.

34 For persecutions of Manichaeans by Abbasid authorities as described in Arabic sources, starting with those of the caliph al-Mahdi $\left(775^{-785}\right)$, see Reeves, Prolegomena, $235 \mathrm{ff}$. The later history of the Manichaean Church in Mesopotamia and Iran is chiefly known from the reliable account of al-Nadim. He recounts a schism between the Mesopotamian and Sogdian branches in the early seventh century, in continuation of a conflict from the sixth century, that was only finally healed under the imam (archegos) Abu Sa'id Raha (see Dodge, The Fihrist, II, 793). Flügel quotes an Iranian Muslim scholar, Shahrastani, who put Raha as active in 884 (Flügel, Mani, seine Lehre, 328). According to al-Nadim, the imam left Mesopotamia altogether shortly afterwards. He had, however, still known 'about three hundred of them (i.e. Manichaeans)' in Baghdad at the time of the governor Mu'izz al-Dawlah (946-67), i.e. in the mid-tenth century CE; but says that at the time of writing (c.990 CE): 'there are not five of them in our midst', trans. Dodge, The Fihrist, II, 803. At this time, the Manichaeans were mainly located in Rustaq (in northern Afghanistan?), Samarkand, Sughd (Sogdia), and especially Tunkath (near Tashkent). The leadership had apparently re-located to Samarkand. 